DOI: 10.17707/AgricultForest.61.2.06

\author{
Snežana TRIFUNOVIĆ, Ana TOPALOVIĆ, \\ Mirko KNEŽEVIĆ, Vlatka VAJS ${ }^{1}$
}

\title{
FREE RADICALS AND ANTIOXIDANTS: ANTIOXIDATIVE AND OTHER PROPERTIES OF SWISS CHARD (Beta vulgaris L. subsp. cicla)
}

\begin{abstract}
SUMMARY
Scientific interest around antioxidative activity of plant extracts and natural compounds as well as their benefit to human health has significantly increased during the past few decades. Fruits and vegetables, as very important sources of antioxidants, have also been much studied. Antioxidants can neutralize free radicals and other reactive oxygen and nitrogen species and help preventing oxidative stress and damage to tissues which could result ageing and most chronic diseases (cardiovascular, neurodegenerative, autoimmune etc.). There are many in vitro assays for estimation of antioxidative activity. The assay must be chosen precisely to best represent the overall antioxidant activity of a plant, what is also important when different plants and their antioxidant capacities are compared. In this paper, main oxidants and their interaction with biomolecules, as well as some diet antioxidants and their mechanism of action are briefly described. Chemical composition, nutritional value, antioxidative, antiproliferative, hypoglycemic and other properties of different Swiss chard (Beta vulgaris L. subsp. cicla) extracts are discussed.
\end{abstract}

Keywords: free radicals, antioxidants, flavonoids, Swiss chard, Beta vulgaris cicla.

\section{INTRODUCTION}

In view of increasing risk factors of various serious diseases, in recent years human health has assumed an extraordinarily important status. A new diethealth model, which places more emphasis on the 'functional' food, is developing. Actually, food should provide additional physiological benefit, such as preventing of chronic diseases, besides fulfilling basic nutritional requirements - to be source of fibers and important dietary micronutrients. There are a lot of studies which evidence a clear connection between intake of fruits and vegetables and reduced risks of cardiovascular diseases, different cancers, autoimmune diseases, atherosclerosis, Alzheimer's disease, cataracts, many other degenerative

\footnotetext{
1 Snežana Trifunović (corresponding author: snezanat@chem.bg.ac.rs), Faculty of Chemistry, University of Belgrade, Studentski trg 12-16, 11058 Belgrade, Serbia; Ana Topalović, Mirko Knežević, Biotechnical Faculty, University of Montenegro, Mihaila Lalića 1, 81000 Podgorica, Montenegro; Vlatka Vajs, Institute of Chemistry, Technology and Metallurgy, University of Belgrade, Studentski trg 12-16, 11058 Belgrade, Serbia.

Notes: The authors declare that they have no conflicts of interest. Authorship Form signed online.
} 
diseases, as well as ageing (Boeing et al., 2012; Yahia, 2010; Sindhi et al., 2013; Steimez et al., 1996; Rimm et al., 1996; Block et al., 1992; Lampe, 1999). Consequently, phytochemicals in fruits and vegetables have attracted a great attention because of their role in preventing diseases mainly those caused by oxidative stress. It is known that oxidative stress, which is connected with imbalanced levels of free radicals and antioxidants, has been implicated in a number of disorders, including above-mentioned. Many fruits and vegetables constituents act as antioxidants and scavengers of free radicals, saving the cells and body on that way (Kaur and Kapoor, 2001; Shetty et al., 2013). Their structures and mechanism of action can be very diverse such as in the case of ascorbic acid, carotenoids, and phenolic compounds.

Many papers deal with estimation of fruits and vegetables antioxidant capacities (Ninfali et al., 2005; Gacche et al., 2010; Chu et al., 2002; Cao et al., 1996; Chun et al., 2005, Ismail et al., 2004, Topalović et al., 2013). One of the most comprehensive screenings of total antioxidants in dietary plants was given by Halvorsen et al. (2002). Besides, these authors reported total antioxidant capacity of more than 3100 fruits, vegetables, beverages, spices and herbs in addition to common everyday foods examined over a period of eight years (Carlsen et al., 2010). Regarding antioxidative properties, Beta vulgaris subsp. cicla was also estimated few times (Pyo et al., 2004; Gennari et al., 2011; Sacan and Yanardag, 2010). These data together with evidences about chemical composition of Swiss chard are reviewed in this paper, besides some general characteristics of free radicals and nutrient antioxidants.

\section{Free radicals}

Free radicals are very reactive species, which half-life is sometimes only few nanoseconds. Most free radicals in biological systems are produced under physiologic or pathologic conditions. Their role could be beneficial when they serve as signaling and regulatory molecules at physiologic levels, but they could be damaging and cytotoxic oxidants at pathologic levels. They can be generated from either endogenous or exogenous sources.

Endogenous free radicals are generated from immune cell activation, inflammation, mental stress, excessive exercise, ischemia, infection, cancer, aging etc. Exogenous free radicals result from environmental influence as air and water pollution, heavy or transition metals $(\mathrm{Cd}, \mathrm{Hg}, \mathrm{Pb}, \mathrm{Fe}, \mathrm{As})$, certain drugs (cyclosporine, tacrolimus, gentamycin, bleomycin), industrial solvents, cooking (smoked meat, used oil, fat), cigarette smoke and radiation (Pham-Huy et al., 2008; Devasagayam et al., 2004; Fang et al., 2002).

Reactive oxygen species (ROS) include the most reactive and damaging hydroxyl $\left({ }^{\bullet} \mathrm{OH}\right)$, superoxide $\left(\mathrm{O}_{2}{ }^{\bullet}\right)$, hydroperoxyl $\left(\mathrm{HOO}^{\bullet}\right)$, peroxyl $\left(\mathrm{ROO}^{\bullet}\right)$ and alkoxyl $\left(\mathrm{RO}^{\bullet}\right)$ radicals, while reactive nitrogen species (RNS) include nitric oxide $\left(\mathrm{NO}^{\bullet}\right)$, peroxynitrite $\left(\mathrm{ONOO}^{\circ}\right)$ and some other radicals. Besides, ROS/RNS involve non-radical reactive species, such as singlet oxygen $\left({ }^{1} \mathrm{O}_{2}\right)$, 
hydrogen peroxide $\left(\mathrm{H}_{2} \mathrm{O}_{2}\right)$, hypochlorous acid $(\mathrm{HOCl})$, hypobromous acid $(\mathrm{HOBr})$ and peroxynitrous acid $(\mathrm{ONOOH})$.

ROS and RNS can be formed in the cells by enzymatic and non-enzymatic reactions. The non-enzymatic process generating free radicals is oxidative phosphorylation in the mitochondria. Mitochondria are the major source of free radicals, and up to five percent of the oxygen used by mitochondria to generate ATP results in the formation of superoxide radicals. Enzymatic reactions include those involved in the respiratory chain, the phagocytosis, the prostaglandin synthesis and the cytochrome P450 system (Pham-Huy et al., 2008).

Most cells can produce superoxide, hydrogen peroxide and nitric oxide on demand, which indicates beneficial role of free radicals for some processes (Devasagayam et al, 2004). Beneficial effects of free radicals involve their role in the body's defence against disease. For example, the immune system's cells phagocytes use oxidative free radicals to destroy viruses and bacteria. They have an important beneficial role and attend biochemical pathway and some mechanism of apoptosis of defective cells. Besides, free radicals play a role in many regulatory functions trough cell signaling pathways. Nitric oxide (NO) is one of intercellular messengers which modulate blood flow, thrombosis, and neural activity (Pacher et al., 2007). It is also important for nonspecific host defence, and for destroying intracellular pathogens and tumors (Pham-Huy et al., 2008).

Excess of free radicals and oxidants in relation to level of antioxidants could cause oxidative stress, a harmful process that can seriously alter the cell structures, e.g. membranes, interacting with biomolecules -lipids, lipoproteins, proteins and nucleic acids.

\section{Free radicals and biomolecules}

Lipids of cell and subcellular membranes are highly sensitive to free radicals and can undergo very damaging chain reaction of lipid peroxidation. This process leads to alteration of the biophysical properties of the membrane (e.g. the degree of fluidity) and can lead to inactivation of membrane-bound receptors or enzymes, which in turn may impair normal cellular function. Beginning of lipid peroxidation is attack of free radical, which abstract a hydrogen atom from methylene group, and formation of carbon radical $\left({ }^{\bullet} \mathrm{CH}\right)$. This radical is stabilized by molecular rearrangement to produce a conjugated diene. Reaction of this new-formed group with an oxygen lead to formation of a lipid peroxyl radical. These radicals can further take out hydrogen atoms from other lipid molecules to form lipid hydroperoxides and propagate the reaction at that way. Lipid peroxidation can be terminated by a number of reactions. The major one involves the reaction of lipid radical or lipid peroxyl radical with a molecule of antioxidant (e.g. vitamin E or tocopherol) which can form more stable radicals that is not involved in further chain reactions and can be 'recycled' by other cellular antioxidants (vitamin $\mathrm{C}$ or glutathione). Additional harmful effect of lipid peroxidation is formation of large number of toxic 
byproducts which can covalently modify biomolecules and amplify cellular damage. Most of them are aldehydes, like malondialdehyde, 4-hydroxynonenal and various 2-alkenals, and can also behave as 'second messengers' having effects at different sites from that of their generation. Lipid peroxidation of arachidonic acid leads to formation of isoprostanes, mediators of oxidative stress (Devasagayam et al., 2004; Ramarathnam et al., 1995; Fang et al., 2002; Montuschi et al., 2004).

Free radicals can attack carbohydrates which are elements of important biomolecules (e.g. hyaluronic acid) abstracting a hydrogen from one of the carbon atoms. Production of a carbon radical in carbohydrate moiety mainly leads to the chain breaks and functional disorder of complex carbohydratecontaining biopolymers.

One path of DNA oxidative damage is also abstractions of hydrogen atoms from the sugar part by free radical such as ${ }^{\circ} \mathrm{OH}$. Besides, the mechanisms of DNA damage involve addition reactions and formation of ${ }^{\bullet} \mathrm{OH}-$ or ${ }^{\bullet} \mathrm{H}$ - adduct radicals of heterocyclic bases. In DNA molecules the most sensitive to be attacked by ${ }^{\circ} \mathrm{OH}$ is $\mathrm{C}(4)-\mathrm{C}(5)$ double bond of pyrimidine, giving oxidative products such as thymine glycol, uracil glycol, urea residue, 5hydroxydeoxyuridine, 5-hydroxydeoxycytidine, hydantoin and other. Similarly, an interaction of the hydroxyl radical with purines generates a series of characteristic purine oxidative products. Oxidative damage to DNA is implicated in mutagenesis, carcinogenesis and aging; e.g. 8-hydroxydeoxyguanosine has been implicated in carcinogenesis and is considered a reliable marker for oxidative DNA damage (Devasagayam et al., 2004; Dizdaroglu et al., 2002).

Oxidative damage to proteins may be of particular importance since the loss of protein function may affect the activity of enzymes, receptors and membrane transporters, among others. Proteins in interaction with free radicals and other reactive oxygen species give stable or reactive products which generate additional radicals particularly upon interaction with transition metal ions. As a result of free radical exposure, many changes can occur in proteins, including amino acid modification, fragmentation, aggregation, changes in absorption and fluorescence spectra, decrease or loss of biological function, or increase in proteolytic susceptibility. All these modifications can be used as markers of protein damage by free radicals. Most oxidized, functionally inactive proteins are rapidly removed, but some can accumulate with time and thereby contribute to the damage associated with ageing as well as various diseases. For example, lipofuscin, an aggregate of peroxidized lipids and proteins accumulates in lysosomes of aged cells and brain cells of patients with Alzheimer's disease (Salvi et al., 2001; Devasagayam et al., 2004; Stadtman, 1992).

\section{Classification of antioxidants}

Oxidative stress plays a major part in the development of chronic and degenerative diseases. Antioxidants are capable of neutralizing free radicals or their actions, acting at different levels of prevention, interception and repair. 
They can be naturally generated (endogenous antioxidants) or externally supplied through foods (exogenous antioxidants). Endogenous antioxidants include enzymatic or non-enzymatic compounds. The major antioxidant enzymes which are in the first line defence are superoxide dismutase (SOD), catalase (CAT), glutathione peroxidase (GP) and glutathione reductase (GR). Minerals like Se, $\mathrm{Cu}, \mathrm{Zn}, \mathrm{Mn}$ are exogenous antioxidants required for enzymes function (Sindhi et al., 2013; Irshad and Chaudhuri, 2002; Pham-Huy et al., 2008).

The antioxidants belonging to the second line defence include metabolic antioxidants such as glutathione (GSH), albumin, coenzyme Q10, lipoic acid, melatonin and uric acid, and nutrient (exogenous) antioxidants such as vitamin $\mathrm{C}$, vitamin $\mathrm{E}, \beta$-carotene (provitamin A), lycopene, flavonoids and other phenolic compounds, etc. The third line defence antioxidants comprise complex group of enzymes for repair of damaged DNA, damaged proteins, oxidized lipids and peroxides i.e. lipase, protease, DNA repair enzymes, transferases, methionine sulphoxide reductase etc. (Sindhi et al., 2013).

The principal defence enzyme superoxide dismutase catalyzes reduction of superoxide anion radical $\left(\mathrm{O}_{2}{ }^{-}\right)$into hydrogen peroxide which is further transformed into water and oxygen by catalase or glutathione peroxidase enzymes. Hydrogen peroxide is used for oxidation of glutathione (GSH) by selenoprotein GP enzyme and removed in this way. Glutathione peroxidase also reduces lipid or nonlipid hydroperoxides oxidizing GSH. Flavoprotein enzyme glutathione reductase regenerates GSH from oxidized form with NADPH (PhamHuy, 2008; Young and Woodside, 2001).

Glutathione is the most abundant non-protein thiol and a major component of the cellular antioxidant system. It is synthesized from glutamate, cysteine and glycine or can be partly absorbed in the diet from the small intestine and can be synthesized de novo, so GSH is an exogenous and endogenous antioxidant (Fang et al., 2002). Besides it acts as a substrate for GP enzyme, GSH is scavenger of different free radicals (Irshad and Chaudhuri, 2002).

\section{Some nutrient antioxidants}

Nutrition can effect on free radical production and also their removal from the body in a way that food constituents influence on a production of endogenous antioxidants as well as act as exogenous antioxidants or even being prooxidant. However, nutrient antioxidants are compounds which cannot be produced in the body and must be provided through foods or supplements. Their deficiency is one of the causes of numerous chronic and degenerative disorders. Each nutrient antioxidant is unique in terms of its structure and antioxidant function (PhamHuy et al., 2008).

\section{Vitamins and minerals}

Vitamin $C$, vitamin $E$, selenium, $\beta$-carotene and other carotenoids $(\alpha-$ carotene, $\beta$-cryptoxanthin, lutein, lycopene, and zeaxanthin) have most frequently been considered dietary antioxidants and in some cases they counteract oxidative 
damage to biomolecules. Hence, the possibility exists that increased intakes of these compounds may protect against chronic disease. Even though the compounds have been classified as antioxidant nutrients, they are multifunctional and some of the actions observed in vivo may also represent their other function (Sies and Stahl, 1995).

Vitamin C (Ascorbate $\mathrm{AscH}^{-}$), a water-soluble antioxidant, is found in both animals and plants. In humans, it is present in aqueous compartments cytosol, plasma and other fluids. It is a reducing agent (high redox potential) and thereby can neutralize reactive oxygen species (for example ${ }^{\bullet} \mathrm{OH}, \mathrm{ROO}^{\bullet}, \mathrm{RO}^{\bullet}$ ) donating a hydrogen atom and thereby becoming an ascorbate radical $\left(\mathrm{Asc}^{\bullet}\right)$ (Fig. 1A). Because of its resonance structure ascorbate free radical is very stable and it does not react by an addition reaction with $\mathrm{O}_{2}$ to form dangerous peroxyl radicals. Besides, it can be restored by NADH or NADPH-dependent reductases. Vitamin $\mathrm{C}$ is also very important for neutralizing the radical form of other significant antioxidants, such as glutathione and vitamin $\mathrm{E}$ and their recycling in that way. On the other hand, vitamin $\mathrm{C}$, in small amounts, in the presence of metal ions (e.g. $\mathrm{Fe}^{3+}$ and $\mathrm{Cu}^{2+}$ ) can act as prooxidant. Large amounts of vitamin $\mathrm{C}$ restore the antioxidant function (Buettner and Jurkiewicz, 1996; Sies and Stahl, 1995).

Vitamin E, fat-soluble vitamin, occurs in nature in at least eight different isoforms $(\alpha-, \beta-, \gamma-, \delta$-tocopherols and tocotrienols). Tocotrienols consist of a chromanol nucleus and a lipophilic isoprenoid chain, while tocopherols differ only in the side chain (phytyl) (Fig. 1B). Humans absorb all forms of vitamin E but in different extent and each of these forms of vitamin $\mathrm{E}$ has a reportedly different biopotency (Brigelius-Flohe and Traber, 1999; Packer et al., 2001). The antioxidant efficacy of tocotrienols in membranes is higher than that of tocopherols, although their uptake and distribution after oral ingestion are less than that of $\alpha$-tocopherol.

Vitamin $\mathrm{E}$ as the major chain-breaking antioxidant in humans is incorporated into cellular membranes in which it effectively interrupts lipid peroxidation. Both tocopherols and tocotrienols scavenge the chain-propagating peroxyl radical (Hamid et al., 2010; Packer et al., 2001). Vitamin E act synergistically with other antioxidants; after quenching lipid radicals it is returned back to its reduced native state directly by vitamin $\mathrm{C}$ or indirectly through thiol antioxidants (glutathione and lipoic acid). Unlike water-soluble antioxidants, $\alpha$-tocopherol efficiently protects glutathione peroxidase deficient cells from cell death. GP is the only enzyme that efficiently reduces lipidperoxides within biological membranes (Herrera and Barbas, 2001).

Carotenoids can be synthesized by plants, bacteria, fungi, and algae, but humans and many animals incorporate them from their diet. So-called provitamin A carotenoids are used as a source of vitamin A. Carotenoids are the most effective singlet oxygen quenchers and can also scavenge peroxyl radicals. Plants synthesize these phytochemicals to protect themselves from singlet oxygen produced by UV light. They are among the most common natural pigments, and 
more than 600 different compounds are known, with $\beta$-carotene as the foremost (Olson and Krinsky, 1995). Approximately 50 carotenoids are present in the human diet and can be absorbed and metabolized by the human body. However, only six of them ( $\beta$-carotene, $\beta$-cryptoxanthin, $\alpha$-carotene, lycopene, lutein and zeaxanthin) account for more than 95\% of total blood carotenoids (Mueller and Boehm, 2011). Basal structure of carotenoids is 40-carbons skeleton which includes a system of conjugated double bonds. The pattern of conjugation influences the antioxidant activity of carotenoids, although the all-E form is predominant in nature. Carotenoids are lipophilic and have a tendency to accumulate in lipophilic cell layers like membranes or lipoproteins. Their lipophilicity also influences their absorption, transport and excretion in the organism. Carotenoids neutralize singlet oxygen $\left({ }^{1} \mathrm{O}_{2}\right)$ almost entirely by physical quenching. Singlet oxygen is not a free radical, but it has electrons in an excited state and reacts mainly with biomolecules containing double-bonds. In interaction of singlet oxygen with carotenoid molecule, singlet oxygen is restored to its ground state giving the energy to carotenoid which becomes a triplet excited. It returns in stable state without chemical reaction dispersing its energy by interaction with the surroundings. In contrast to physical quenching, chemical reactions between the excited oxygen and carotenoids (results in a dioxide) is of minor importance, contributing less than $0.05 \%$ to the total quenching rate. Carotenoids can be used several times in quenching cycles, because they remain intact during physical quenching of ${ }^{1} \mathrm{O}_{2}$ (Stahl and Sies, 2003; Pham-Huy et al., 2008).

$\boldsymbol{\beta}$-carotene (Fig. 1C) as well as $\boldsymbol{\alpha}$-carotene, $\boldsymbol{\beta}$-cryptoxanthin and zeaxanthin belong to the group of highly active quenchers of singlet oxygen and all are detected in human serum and tissues. The most powerful is the open ring carotenoid lycopene (Fig. 1C), which contributes up to 30\% to total carotenoids in humans. Lutein was found to scavenge superoxide radicals, hydroxyl radicals and inhibited in vitro lipid peroxidation. The oral administration of lutein in mice for 1 month significantly increased the activity of catalase, superoxide dismutase, glutathione reductase and glutathione in blood and liver while the activity of glutathione peroxidase and glutathione-S-transferase were found to be increased in the liver tissue (Sindhu et al., 2010).

The selenium in several selenoproteins has a biochemical role in oxidant defence, thus maintaining normal physiological function, and as such plays a role as a dietary antioxidant. The criterion used to estimate the requirement for selenium relates to the intake needed to maximize the activity of the plasma selenoprotein glutathione peroxidase, an oxidant defence enzyme (Food and Nutrition Board, Institute of Medicine Washington, 2000). Selenoprotein P is believed to be involved in endothelial protection during sepsis, regulating intracellular pathways that are activated by oxidative stress and free radicals. In foods, Se is predominantly present as selenomethionine, which is an important source of dietary Se in humans. Alternatively, at high doses seleno-compounds can have a damaging, pro-oxidant effect. 
A<smiles>[R][CH]C(O)C1OC(O)=C(O)C1=O</smiles>

B
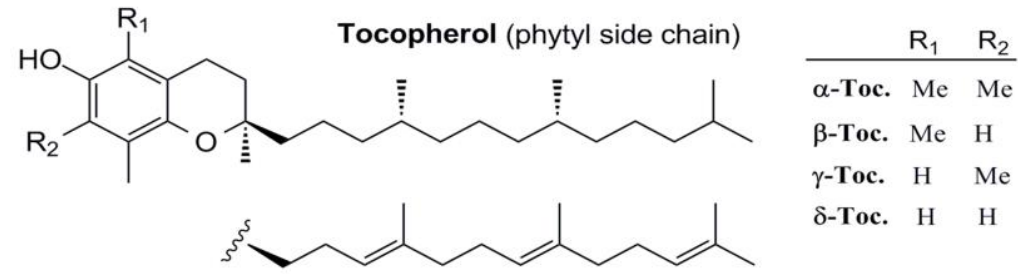

Tocotrienol (isoprenoid side chain)

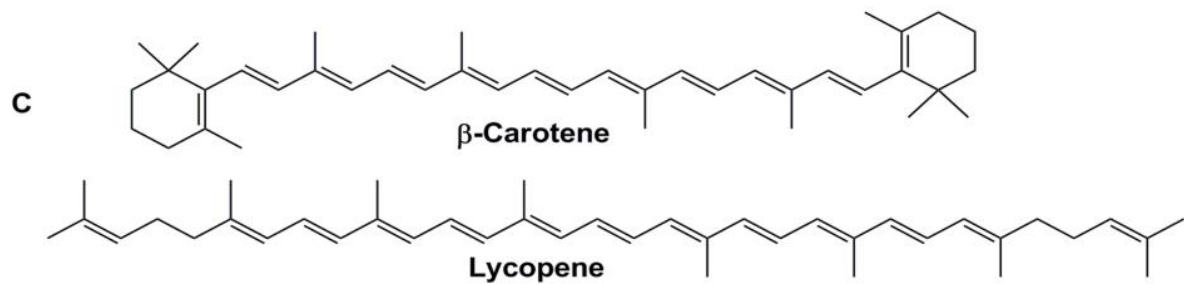

Figure 1. Structures of some nutrient antioxidants. A) Vitamin C; B) Vitamin E; C) $\beta$-carotene and lycopene

\section{Phenolic compounds and other phytochemicals}

Phytochemicals are defined as bioactive non-essential nutrients from plants. Plants produce these chemicals to protect themselves, although they usually exhibit a variety of human health effects. Among the great structural diversity of phytochemicals, phenolic compounds have attracted most attention for their diverse bioactivities. Phenolic compounds are essential in the reproduction and growth of plants, defend plants from pathogens, parasites and predators, as well as contribute to the color of fruits, leaves and flowers, what attracts insects for pollination. Their physiological and pharmacological functions may originate from their antioxidant and free radical scavenging properties and function of regulating detoxifying enzymes. Further, these antioxidant activities are related to the structures of phenolic compounds, generally depending on the number and positions of hydroxyl groups and glycosylation or other substitutions (Heim et al., 2002; Huang et al., 2010). Main group of phenolic compounds include phenolic acids, flavonoids, tannins, stilbenes, curcuminoids, coumarins, lignans, quinines and other phenylethanoids and phenylpropanoids. The antioxidant activity of phenolics is mainly due to their redox properties, which allow them to act as reducing agents, hydrogen donators, and radical and singlet oxygen quenchers. In addition, they have a 
metal chelation potential (Kähkönen et al., 1999; Rice-Evans et al., 1995; Leopoldini et al., 2004).

Flavonoids are largest group of phenolic compound with more than 4000 compounds isolated till now. Their structure is based upon fifteen-carbon skeleton consisting of two benzene rings (A and B, Fig. 2) linked via a heterocyclic pyrane ring (C, Fig. 2). They can be divided into a variety of classes such as flavones, flavonols, flavanones, flavanonols, isoflavones, flavan-3-ols and oligomeric flavonoids such as proanthocyanidins and tannins.

Flavonoids occur as aglycones, glycosides, and methylated derivatives. They possess many biochemical properties, but the best described property of almost every group of flavonoids is their capacity to act as antioxidants. The antioxidant activity of flavonoids depends upon the arrangement of functional groups about the nuclear structure. The configuration, substitution and total number of hydroxyl groups, as well as the availability of phenolic hydrogens and the possibility of stabilization of the resulting phenoxyl radicals, via hydrogen bonding or by expanded electron delocalization, substantially influence several mechanisms of antioxidant activity (Kumar and Pandey, 2013; Amić et al., 2003; Leopoldini et al., 2004). The $\mathbf{B}$ ring hydroxyl configuration is the most significant determinant of scavenging of ROS and RNS because it donates hydrogen and an electron to hydroxyl, peroxyl, and peroxynitrite radicals (Kumar and Pandey, 2013; Cao et al., 1997). Two main mechanisms by which flavonoids can act (hydrogen donating and giving an electron) are presented below:

$\mathrm{R}^{\bullet}+$ Flavonoid $\mathbf{O H}=\mathrm{RH}+$ Flavonoid $^{\bullet}(\mathrm{H}$-atom transfer $)$

$\mathrm{R}^{\bullet}+$ Flavonoid $\mathrm{OH}=\mathrm{R}^{-}+$Flavonoid $\mathrm{OH}^{\bullet+}$ (the one-electron transfer)

Besides scavenging ROS, flavonoids also exhibit their antioxidant action suppressing ROS formation by inhibition of enzymes or by chelating trace elements (iron, copper, etc.) involved in free radical generation. Enzymes inhibited by flavonoids involve microsomal monooxygenase, glutathione Stransferase, mitochondrial succinoxidase, NADH oxidase, etc. Flavonoids play an important role in protection lipid of peroxidation (Kumar and Pandey, 2013); they can reduce LDL peroxidation (Cao et al., 1997).<smiles></smiles><smiles>O=C1c2ccccc2O[C@H](c2ccccc2)[C@@H]1O</smiles><smiles>OC1Cc2ccccc2O[C@H]1c1ccccc1</smiles><smiles>O=c1c(O)c(-c2ccccc2)oc2ccccc12</smiles><smiles>O=c1c(-c2ccccc2)coc2ccccc12</smiles>

Isoflavones<smiles>O=C1C[C@H](c2ccccc2)Oc2ccccc21</smiles>

Flavanones<smiles>Oc1cc2ccccc2[o+]c1-c1ccccc1</smiles>

Anthocyanidins

Figure 2. Flavonoids - structural classification 


\section{Methods for antioxidant activity screening}

There is a long list of diet plants with antioxidative properties and many of them are in everyday use as fruits and vegetables, spices, herb oils and teas. Their antioxidative capacities are screening by different in vitro methods (Gupta and Sharma, 2006; Shalaby and Shanab, 2013). The different types of methods published in the literature involve more than one mechanism: hydrogen atom transfer (HAT), electron transfer (ET), and, in addition, metal chelating or free radical scavenging activity (Tables 1, Shalaby and Shanab, 2013).

Table 1. List of in vitro antioxidant methods (from ref. Shalaby and Shanab, 2013)

\section{In vitro antioxidant methods}

\begin{tabular}{|c|c|c|}
\hline $\begin{array}{c}\text { Hydrogen atom } \\
\text { transfer methods } \\
\text { (HAT) }\end{array}$ & $\begin{array}{l}\text { Electron transfer } \\
\text { methods (ET) }\end{array}$ & Other assays \\
\hline $\begin{array}{l}\text { Oxygen radical } \\
\text { absorbance capacity } \\
\text { (ORAC) method }\end{array}$ & $\begin{array}{lr}\text { Trolox } & \text { equivalent } \\
\text { antioxidant } & \text { capacity } \\
(\mathrm{TEAC}) \text { decolourization }\end{array}$ & $\begin{array}{l}\text { Total oxidant scavenging } \\
\text { capacity (TOSC) }\end{array}$ \\
\hline $\begin{array}{l}\text { Lipid peroxidation } \\
\text { inhibition capacity } \\
(\text { LPIC) assay }\end{array}$ & $\begin{array}{lr}\text { Ferric } & \text { reducing } \\
\text { antioxidant } & \text { power } \\
\text { (FRAP) } & \\
\end{array}$ & $\begin{array}{l}\text { Inhibition of Briggs- } \\
\text { Rauscher oscillation reaction }\end{array}$ \\
\hline $\begin{array}{l}\text { Total radical } \\
\text { trapping antioxidant } \\
\text { parameter (TRAP) }\end{array}$ & $\begin{array}{l}\text { DPPH free radical } \\
\text { scavenging assay }\end{array}$ & Chemiluminescence \\
\hline $\begin{array}{l}\text { Inhibited oxygen } \\
\text { uptake (IOC) }\end{array}$ & $\begin{array}{lll}\begin{array}{l}\text { Copper } \\
\text { capacity }\end{array} & \text { reduction } \\
\text { calion } & \\
\end{array}$ & Electrochemiluminescence \\
\hline $\begin{array}{l}\text { Crocin bleaching } \\
\text { Nitric oxide radical } \\
\text { inhibition activity }\end{array}$ & $\begin{array}{l}\text { Total phenols by Folin- } \\
\text { Ciocalteu }\end{array}$ & Fluorometric analysis \\
\hline $\begin{array}{l}\text { Hydroxyl radical } \\
\text { scavenging activity } \\
\text { by p-NDA } \\
\text { ( } p \text {-butrisidunethyl } \\
\text { aniline) }\end{array}$ & $\begin{array}{l}\text { N,N-dimethyl- } p \text { - } \\
\text { phenylenediamine } \\
\text { (DMPD) assay }\end{array}$ & $\begin{array}{l}\text { Enhanced chemiluminescence } \\
\text { (ECL) }\end{array}$ \\
\hline $\begin{array}{l}\text { Scavenging of } \mathrm{H}_{2} \mathrm{O}_{2} \\
\text { radical }\end{array}$ & & TLC bioautography \\
\hline $\begin{array}{l}\text { ABTS radical } \\
\text { scavenging method }\end{array}$ & & $\begin{array}{l}\text { Cellular antioxidant activity } \\
\text { (CAA) assay }\end{array}$ \\
\hline $\begin{array}{l}\text { Scavenging of super } \\
\text { oxide radical } \\
\text { formation r by } \\
\text { alkaline SASA }\end{array}$ & & $\begin{array}{l}\text { Dye-substrate } \\
\text { method }\end{array}$ \\
\hline
\end{tabular}

SWISS CHARD (Beta vulgaris L. subsp. cicla) antioxidative and other properties

Swiss chard is a biennial leafy vegetable cultivated worldwide, the most in northern India, South America, the Mediterranean countries and USA. It is an 
important crop because of its year round availability, high yield, low cost, and an abundance of minerals, vitamins and phenolic compounds. The leaves and the stems are the edible parts used in many traditional dishes, in salads or cooked.

It is a member of the family Chenopodiaceae, genus Beta, which in the cultivated group comprises sugar beets (Beta vulgaris saccharifera), fodder beets (Beta vulgaris crassa), leaf beets (Beta vulgaris cicla) and garden beets (Beta vulgaris rubra) (Lange et al., 1999; Ninfali and Angelino, 2013). Swiss chard (Beta vulgaris subspecies cicla) is sometimes also called stem chard because of its broad and flat stalks (Pyo et al., 2004). This species has many varieties (some distinctive in color) and many cultivars (Fig. 3).

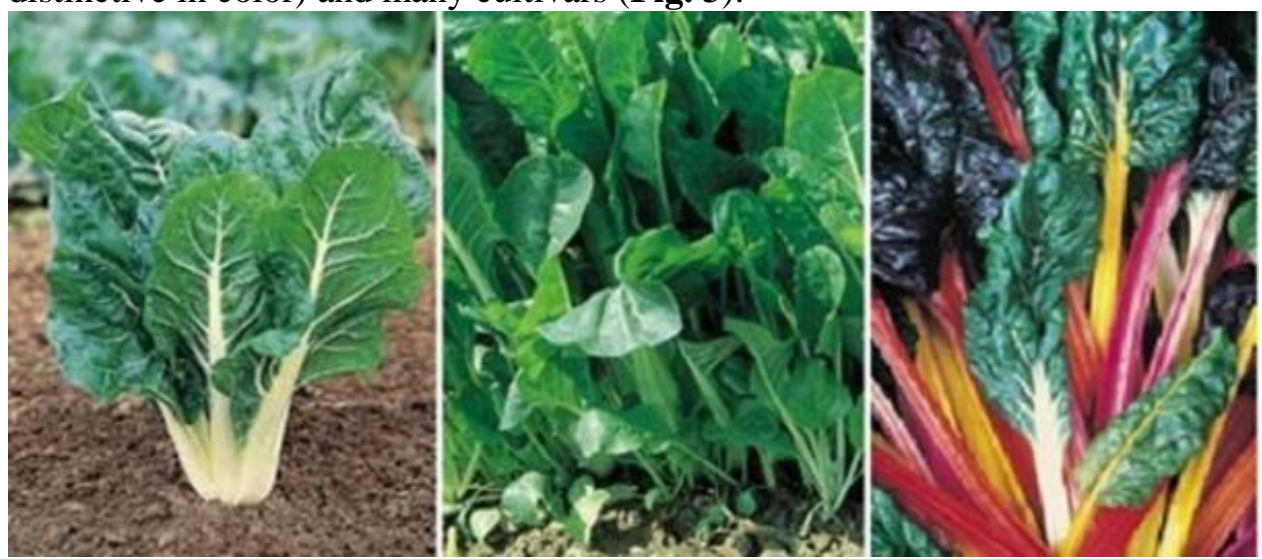

Figure 3. Pictures of the main cultivars of Beta vulgaris var. cicla. A) Swiss chard - bieta costa bianca; B) Swiss chard - bieta erbetta da taglio; C) Swiss chard - Hybrid F1 (from ref. Ninfali and Angelino, 2013)

Nutritional quality and chemical composition of different varieties and cultivars of Beta vulgaris subsp. cicla were investigated including antioxidant, anti-diabetic, anticancer and some other biological activities (Ninfali et al. 2007; Ninfali and Angelino, 2013; Pyo et al., 2004; Sacan and Yanardağ, 2010; Gil et al., 1998; Bozokalfa et al., 2011; Tomás-Callejas et al., 2011; Pokluda and Kuben, 2002; Gennari et al., 2011; Santos et al., 2014; Yanardağ and Çolak, 1998; Bolkent et al., 2000; Ninfali and Bacchiocca, 2003). Phenolic content and antioxidant activities have been most frequently studied. In comparison with other largely consumed vegetables in the Mediterranean diet, Swiss chard is displaying high antioxidant activity (Bolkent et al., 2000).

Significant concentrations of nutrients were recorded in different samples of Swiss chard. Together with field experiments focused on the observation of morphological characteristics, the nutritive values of leaves and stalks of 12 Swiss chard varieties were estimated. The mean values of nutritional parameters of examined varieties were as follows: vitamin C -307 and $72 \mathrm{mg} / \mathrm{kg}, \mathrm{K}-4198$ and $4848 \mathrm{mg}, \mathrm{Na}-2101$ and $966 \mathrm{mg}, \mathrm{Ca}-481$ and $310 \mathrm{mg}$ and $\mathrm{Mg}-361$ and $113 \mathrm{mg} / \mathrm{kg}$ of fresh matter (f.m.), always in leaves and stalks, respectively (Pokluda and Kuben, 2002). Another study of mineral composition of Swiss 
chard included the seeds of 54 genetically diverse Swiss chard accessions, representative of all Turkish genetic resources of this plant. The evaluation of germplasm diversity in the nutritional concentration context is useful for further breeding programmes, because of improvement of mineral concentrations in Swiss chard cultivars and contribution to reduction of nutritional deficiencies in human nutrition. Significant differences among accessions and remarkably high nutrient contents were displayed. The concentrations of measured parameters (based on dry weight) ranged within the following limits: P $5.99-2.38 \mathrm{~g} / \mathrm{kg}, \mathrm{K}$ $49.40-28.60 \mathrm{~g} / \mathrm{kg}, \mathrm{Ca} 4.74-2.66 \mathrm{~g} / \mathrm{kg}, \mathrm{Mg} 9.43-3.33 \mathrm{~g} / \mathrm{kg}, \mathrm{Na} 5.72-2.40$ $\mathrm{g} / \mathrm{kg}$, Fe $159.65-77.22 \mathrm{mg} / \mathrm{kg}$, Cu $16.96-7.60 \mathrm{mg} / \mathrm{kg}$, Zn $65.52-22.31 \mathrm{mg} / \mathrm{kg}$, Mn $33.89-12.57 \mathrm{mg} / \mathrm{kg}$ and ammonium $44.3-28.81 \mathrm{~g} / \mathrm{kg} . \mathrm{NO}_{3}$ and $\mathrm{NO}_{2}$ concentrations were $496.55-262.48 \mathrm{mg} / \mathrm{kg}$ and $0.047-0.024 \mathrm{mg} / \mathrm{kg}$, respectively, based on fresh weight. Two of examined accessions are recommended to be gene sources due to their high levels of $\mathrm{K}, \mathrm{Ca}$ and $\mathrm{Zn}$ (Bozokalfa et al., 2011).

The phenolic composition and content as well as antioxidant activity of methanol-water (8:2), ethanol-water (4:6), methanol, water and ethyl-acetate extracts were analysed.

The methanol-water (8:2) extracts of two cultivar of Swiss chard (green and yellow) were compared regarding flavonoids composition and content, as well as vitamin $\mathrm{C}$ content. Effects of cooking and modified atmosphere packaging were also monitored. Five flavonoids were identified in green cultivar, namely 2"'-xylosylvitexin (1), 8- $C$ - $\beta$ - D - (2'" $\beta$ - D - xylopyranosyl - 6 ', malonyl) glucopyranosyl apigenin (2"'-xylosyl-6"'-malonylvitexin) (2, 6"'Malonyl - 2' - xylosylvitexin), kaempferol 3-gentiobioside (3), isorhamnetin 3gentiobioside (4), isorhamnetin 3-vicianoside (5), but only two, 1 and 2, in yellow cultivar (Gil et al., 1998, Fig. 4). Total flavonoid contents were 2.76 and $1.26 \mathrm{mg} / \mathrm{g}$ of fresh weight, respectively. Concerning the vitamin C content, both cultivars had amounts around $0.45 \mathrm{mg} / \mathrm{g}$ f.w. Also, processing affects antioxidant phenolics and vitamin $\mathrm{C}$ content on this way: $50 \%$ of flavonoids were extracted during the cooking and the rest remained in cooked leaves, while $80 \%$ of the vitamin $\mathrm{C}$ present in the initial tissue was lost during the cooking process (Gil et al., 1998).

A phenolic fraction obtained from ethanol-water (4:6) Swiss chard extract was analysed to be identified following compounds: 2''-xylosylvitexin (1), isorhamnetin 3-gentiobioside (4), vitexin 2''O-rhamnoside (6) as a major and rutin (7), quercetin 7-glucuronide (8), isorhamnetin (9) and apigenin 7-rutinoside (10) as a minor (Fig. 4). A phenolic fraction as a whole and its four separated fractions were characterized for antioxidant capacity, antimitotic activity on MCF-7 human breast cancer cells and for toxicity to human lymphocytes and macrophages (Ninfali et al., 2007). A whole phenolic fraction inhibited MCF-7 cell proliferation $\left(\mathrm{IC}_{50}=9 \mu \mathrm{g} / \mathrm{ml}\right)$ without inducing apoptosis, showed no toxicity to human lymphocytes and slight toxicity to macrophages. Vitexin 2"'Orhamnoside strongly inhibited DNA synthesis in MCF-7 cells, whereas 2"'- 
xylosylvitexin and isorhamnetin 3-gentiobioside were activators, maintaining in combination the inhibitory effect. Vitexin 2"'O-rhamnoside is a component the mainly responsible for most of the antioxidant activity (the ORAC assay) of total phenolic fraction (Ninfali et al., 2007).

A determination of the antioxidant activities by DPPH and thiocyanate methods, total phenolic contents and phenolic composition of $\mathrm{MeOH}$ extracts of leaves, as well as stems of white and red tissue cultivars showed significant differences in the antioxidant activities, phenolic content and composition between leaves and stems. Compounds which are detected were benzoic acids (gallic, protocatechuic, $p$-OH-benzoic and vanillic), cinnamic acids (syringic, chlorogenic, caffeic, $p$-coumaric, ferulic), the flavan-3-ol (+)catechin (11) and flavonols myricetin (12), quercetin (13) and kaempferol (14), Fig. 4). The major phenolic acid and flavonoid in these leaf samples were syringic acid and kaempferol. Using the DPPH radical scavenging method and the thiocyanate method, the antioxidant activity of each extract from Swiss chard was in the order: red leaf $>$ white leaf $>$ red stem $>$ white stem. This result was consistent with the order of total phenolic content of each extract (red leaf $128.1 \mathrm{mg} / 100 \mathrm{~g} \mathrm{f.w.}$., white leaf $101.5 \mathrm{mg} / 100 \mathrm{~g}$ f.w., red stem $29.7 \mathrm{mg} / 100 \mathrm{~g}$ f.w., white stem 23.2/100 g f.w.) (Pyo et al., 2004).

In the water extract of Swiss chard, anthocyanin content was found to be $0.47 \pm 0.03 \mu \mathrm{mol} / \mathrm{g}$. It was also determined that there was $31.09 \pm 3.34 \mu \mathrm{g}$ pyrocatechol equivalent and $11.88 \pm 1.46 \mu \mathrm{g}$ epicatechin equivalent of phenolic compounds in the $1 \mathrm{mg}$ of this extract. A high correlation was observed between the total phenolic content and hydroxyl radical scavenging activity, ABTS ${ }^{*+}$ scavenging activity, DPPH radical scavenging activity, DMPD ${ }^{++}$scavenging activity and reducing power of the extract, which showed that the phenolic content might be responsible for the antioxidant activity. Taking into account that amino acid proline is intracellular nonenzymatic ROS scavenging molecule which provides protecting against stress by maintaining redox homeostasis and scavenging free radicals and ROS, authors additionally determined its content which was $427.74 \pm 24.41 \mu \mathrm{g} / \mathrm{g}$ extract (measured in $10 \mathrm{mg}$ of the extract). In this study in vitro inhibition of acetylcholinesterase by chard extract, with $\mathrm{EC}_{50}$ $=14.43 \pm 2.76 \mu \mathrm{g} / \mathrm{ml}$, was reported for the first time. Given that plants and their extracts have been traditionally used to enhance cognitive function and to alleviate other symptoms associated nowadays with Alzheimer's disease and considering measured antioxidative and antiacetylcholinesterase activities, the conclusion was that chard extract may offer great potential for the treatment of AD (Sacan and Yanardag, 2010).

Beta vulgaris var. cicla leaves contain chemopreventive compounds belonging to the family of the apigenin-glycosides that have been investigated for new drug discovery. However, the leaves as a source of these compounds are easily degradable during storage in fresh conditions and a drying process requires time and a large amount of energy. Due to these facts, the extraction of apigeninglycosides is better to be conveniently performed from the seeds, which represent 
a stable and year-long available biomass (Gennari et al., 2011). Gennari et al. found a strategy of purification of bioactive flavonoids from the seeds and tested their ability to inhibit proliferation on human colon cancer (RKO) cells and normal human fibroblasts (HF). The ethyl-acetate (EA) extract of Beta vulgaris var. cicla seeds was standardized by total phenols $(246.77 \pm 22.9 \mathrm{mg} / \mathrm{g}$ dry extract) and antioxidant activity (4269.76 $\pm 417.4 \mathrm{mMol}$ Trolox equivalents /g dry extract) and showed the antiproliferative activity on RKO cells with $\mathrm{IC}_{50}=32$ $\pm 3 \mathrm{mg} / \mathrm{mL}$ of phenolics. Human fibroblasts, at the lowest dose of the EA extract, showed an enhancement of the proliferation, but higher concentrations induced an inhibitory effect showing $\mathrm{IC}_{50}$ of $62 \pm 6 \mathrm{mg} / \mathrm{mL}$ of phenolics. This extract was fractionated and a flavonoid containing fraction with marked antiproliferative activity on RKO cells were purified and its components were identified by HPLC-ESI-MS as 2,4,5-trihydroxybenzaldehyde, 2,5-dihydroxybenzaldehyde, vanillic acid, xylosylvitexin (1), glucopyranosyl-glucopyrasyl-rhamnetin (15) and glucopyranosyl-xylosyl-rhamnetin (16) (Fig. 4). All of them were tested for cytostatic and cytotoxic activity on RKO and HF cells. The ratio of antioxidant activity determined by ORAC method and phenolics showed an increasing of the antioxidant activity along the purification process (Gennari et al., 2011). Xylosylvitexin, the main and more efficient chemopreventive compound in Swiss chard seeds, represented by $39.44 \%$ in the phenolic fraction, exhibited the strongest antiproliferative activity on RKO cells with an $\mathrm{IC}_{50}$ of $89 \pm 9 \mathrm{mg} / \mathrm{mL}$, together with an enhancement of the apoptosis, an increase of cells in the G1 phase and a reduction of cells in the $\mathrm{S}$ phase. On the contrary, this flavonoidglycoside significantly stimulated proliferation of HF. Finally, xylosylvitexin is the main and more efficient chemopreventive compound in B. vulgaris var. cicla seeds, but the natural mixture of molecules, represented by phenolic fraction, showed a better compromise between the antiproliferative activity on RKO cells and the enhancement of HF proliferation (Gennari et al., 2011).

Swiss chard is used as an antidiabetic agent in folk medicine of Turkey. One of the studies of hypoglycemic properties (Yanardağ and Çolak, 1998) showed that $2-8 \mathrm{~g} / \mathrm{kg}$ doses of aqueous extracts of dried chard leaves decreased the blood glucose of alloxan-induced diabetic rabbits, but methanol extracts did not. Blood sugar-lowering saponins betavulgarosides I -V (17 - 21, Fig. 5.) are extracted and purified from $B$. vulgaris. Betavulgarosides I $-\mathrm{V}$ administered orally to rats markedly lowered blood sugar levels in the animals after glucose loading (Masayuki and Shoichi, 1997). The later study carried out by Bolkent et al. (2000) exhibited that aqueous extract of Swiss chard reduced the blood glucose value in streptozotocin-induced hyperglycemic rats, having no effect on blood glucose and body weight in the normal group. The chard extract acts like an insulinogenic agent in induced diabetic rats. It may decrease glucose levels by increasing insulin secretion from B cells of the pancreas. As a result, Bolkent et al. (2000) assumed that Swiss chard therapy can provide blood glucose homeostasis and can cause regeneration of B cells of endocrine pancreas. The chemical nature of the active principles responsible for the anti-diabetic activity 
of examined aqueous extract is not known, although it is supposed it could be previously reported saponins and flavonoids isolated from this plant.

In diabetes mellitus, increased free radical formation raises the incidence of atherosclerosis and cardiovascular diseases. Investigation of the effect of feeding chard on diabetes-induced free radical-mediated injury in rat aorta and heart tissues indicated that lipid peroxidation was increased and glutathione levels were decreased in both aorta and heart tissue of the diabetic rats. However, the results indicated that treatment with chard extract reversed the effects of diabetes on blood glucose and tissue lipid peroxidation and glutathione levels (Sener et al., 2002).

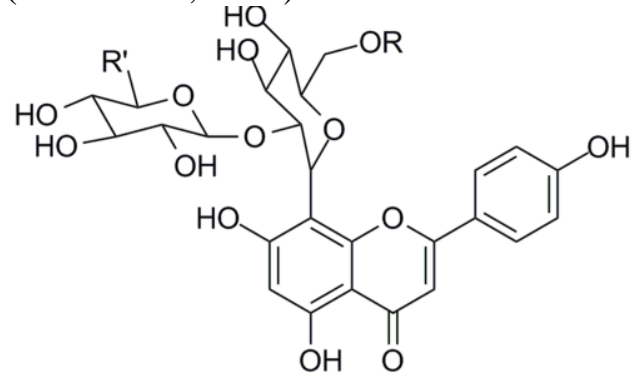<smiles>[R]c1cc(-c2oc3cc(O)cc(O)c3c(=O)c2[R])ccc1O</smiles>

$1 \mathrm{R}=\mathrm{R}^{\prime}=\mathrm{H}$

$2 \mathrm{R}=\mathrm{CO}-\mathrm{CH}_{2}-\mathrm{COOH}, \mathrm{R}^{\prime}=\mathrm{H}$

$6 \mathrm{R}=\mathrm{H}, \mathrm{R}^{\prime}=\mathrm{CH}_{3}$<smiles></smiles>

$8 \mathrm{R}=\mathrm{R}^{\prime}=\mathrm{OH}, \mathrm{R}^{\prime \prime}=\mathrm{GlcA}$

$10 \mathrm{R}=\mathrm{R}=\mathrm{H}, \mathrm{R}^{\prime \prime}=\alpha-\mathrm{L}-\mathrm{Rhap}-[1 \rightarrow 6]-\beta-\mathrm{D}-\mathrm{Gl} c p$

$3 \mathrm{R}=\mathrm{OH}, \mathrm{R}^{\prime}=\beta-\mathrm{D}-\mathrm{Gl} c p-[1 \rightarrow 6]-\beta-\mathrm{D}-\mathrm{Gl} c p$ $4 \mathrm{R}=\mathrm{OCH}_{3}, \mathrm{R}^{\prime}=\beta-\mathrm{D}-\mathrm{Glc} p-[1 \rightarrow 6]-\beta-\mathrm{D}-\mathrm{Gl} c p$ $5 \mathrm{R}=\mathrm{OCH}_{3}, \mathrm{R}^{\prime}=\beta-\mathrm{D}-\mathrm{Ara}-[1 \rightarrow 6]-\beta-\mathrm{D}-\mathrm{Gl} c p$ $7 \mathrm{R}=\mathrm{H}, \mathrm{R}^{\prime}=\alpha-\mathrm{L}-\mathrm{Rhap}-[1 \rightarrow 6]-\beta-\mathrm{D}-\mathrm{Gl} c p$<smiles>[R]c1cc(-c2oc3cc(O)cc(O)c3c(=O)c2O)cc([R])c1O</smiles>

$$
\begin{aligned}
& 9 \mathrm{R}=\mathrm{OCH}_{3}, \mathrm{R}^{\prime}=\mathrm{H} \\
& 12 \mathrm{R}=\mathrm{R}^{\prime}=\mathrm{OH} \\
& 13 \mathrm{R}=\mathrm{OH}, \mathrm{R}^{\prime}=\mathrm{H} \\
& 14 \mathrm{R}=\mathrm{R}^{\prime}=\mathrm{H}
\end{aligned}
$$<smiles>Oc1cc(O)c2c(c1)O[C@H](c1ccc(O)c(O)c1)[C@H](O)C2</smiles>

11<smiles>[R]c1c(-c2ccc(O)c(O)c2)oc2cc(OC)cc(O)c2c1=O</smiles>

$15 \mathrm{R}=\beta$-D-Glcp-[1 $\rightarrow 6]-\beta-\mathrm{D}-\mathrm{Gl} c p$ $16 \mathrm{R}=\beta-\mathrm{D}-\mathrm{Xyl} p-[1 \rightarrow 3]-\beta-\mathrm{D}-\mathrm{Gl} c p$

Figure 4. Phenolic compounds of B. vulgaris var. cicla 

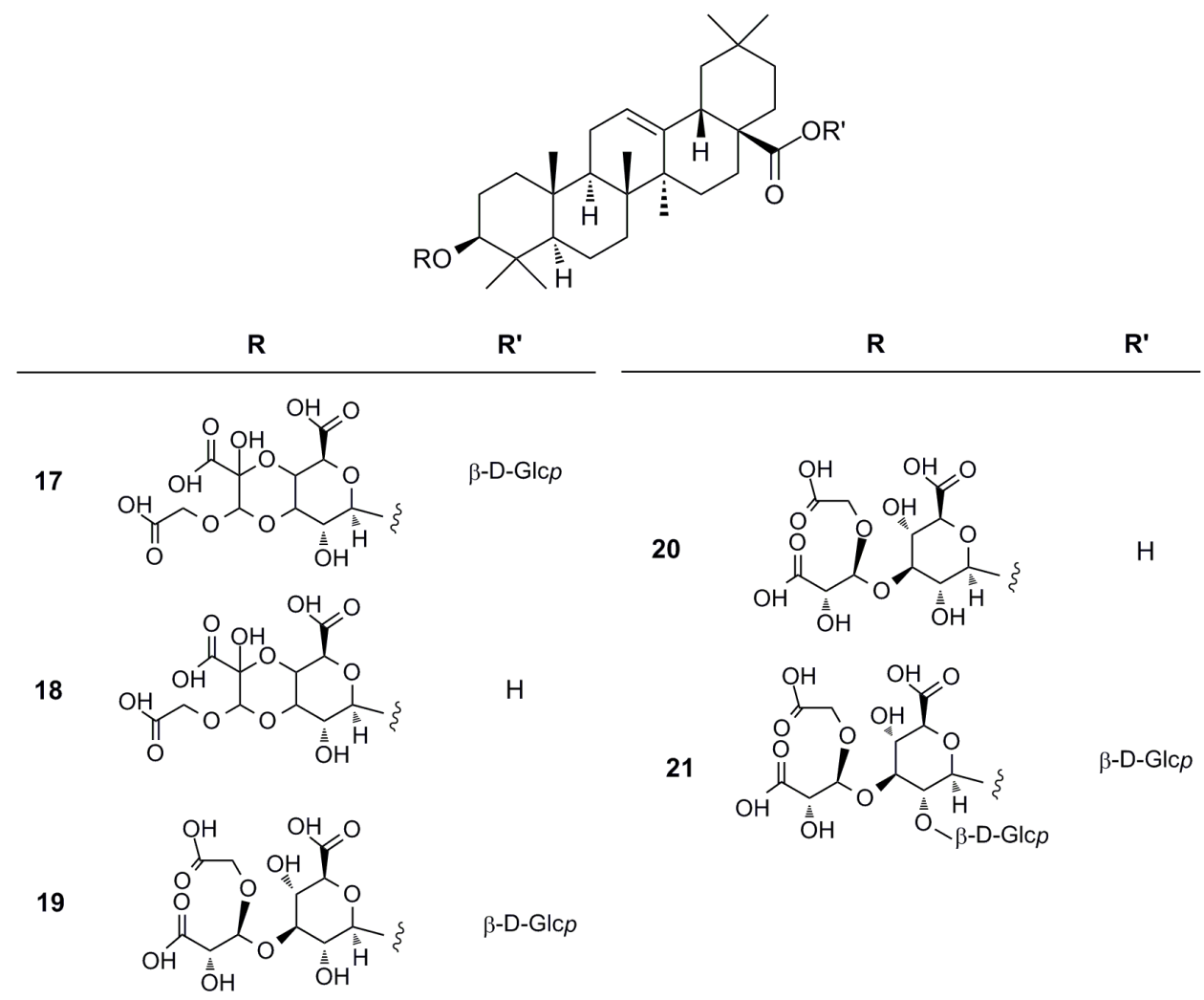

Figure 5. Saponis from B. vulgaris var. cicla

Altogether, Beta vulgaris var. cicla is rich in minerals, vitamins and phytochemicals and presents one of the healthiest vegetables. Main identified secondary metabolites are flavonoids, flavonoid glycosides and saponins. Antioxidative activity of different Swiss chard extracts and their components is proven in several tests, as well as antimitotic activity on MCF-7 human breast cancer cells, antiproliferative activity on human colon cancer and hypoglycemic activity.

\section{REFERENCES}

Amić D., Davidović-Amić D., Bešlo D., Trinajstić N. (2003): Structure-Radical Scavenging Activity Relationships of Flavonoids. Croat. Chem. Acta, 76 (1): $55-61$.

Block G., Patterson B., Subar A. (1992): Fruits, vegetables and cancer prevention: a review of the epidemiological evidence. Nutr. Cancer, 18: 1-29.

Boeing H., Bechthold A., Bub A., Ellinger S., Haller D., Kroke A., Leschik-Bonnet E.,Muller M.J., Oberritter H., Schulze M., Stehle P., Watzl B. (2012): Critical review: vegetables and fruit in the prevention of chronic diseases. Eur. J. Nutr., 51: 637-663. 
Bolkent Ş, Yanardağ R., Tabakoğlu-Oğuz A., Özsoy-Saçan Ö. (2000): Effects of chard (Beta vulgaris L. var. cicla) extract on pancreatic B cells in streptozotocin-diabetic rats: a morphological and biochemical study. J. Ethnopharmacol. 73: 251-259.

Bozokalfa M.K., Yağmur B., Aşçı̆̆ul T.K., Eşiyok D. (2011): Diversity in nutritional composition of Swiss chard (Beta vulgaris subsp. L. var. cicla) accessions revealed by multivariate analysis. Plant Genet Resour-C, 9(4): 557-566.

Brigelius-Flohé R., Traber M. G. (1999): Vitamin E: function and metabolism. FASEB J., 13: 1145-1155 .

Buettner G.R. \& Jurkiewicz B.A. (1996): Catalytic Metals, Ascorbate and Free Radicals: Combinations to Avoid, Rad. Res. 145: 532-541.

Cao G., Sofic E., Prior R. L. (1996): Antioxidant capacity of tea and common vegetables. J. Agric. Food Chem., 44: 3426-3431.

Cao G., Sofic E., Prior R.L. (1997): Antioxidant and prooxidant behavior of flavonoids: structure-activity relationships, Free Radic. Biol. Med., 22: 749-760.

Carlsen .M.H., Halvorsen B.L., Holte K., Bøhn1 S.K., Dragland S., Sampson L., Willey C., Senoo H., Umezono Y., Sanada C., Barikmo I., Berhe N., Willett W.C., Phillips K.M., Jacobs Jr D.R., Blomhoff R. (2010): The total antioxidant content of more than 3100 foods, beverages, spices, herbs and supplements used worldwide. Nutr. J., 9(3): 1-11.

Chu Y.F., Sun J., Wu X., Liu R.H. (2002): Antioxidant and antiproliferative activities of common vegetables. J. Agric. Food Chem., 50 (23): 6910-6916.

Chun O. K., Kim D-O., Smith N., Schroeder D., Han J. T., Lee C. Y. (2005): Daily consumption of phenolics and total antioxidant capacity from fruit and vegetables in the American diet. J. Sci. Food Agric., 85: 1715-1724.

Devasagayam T.P.A., Tilak J.C., Boloor K.K., Sane K.S., Ghaskadbi S.S., Lele R.D. (2004): Free Radicals and Antioxidants in Human Health: Current Status and Future Prospects. JAPI, 52: 794-804.

Dizdaroglu M., Jaruga P., Birincioglu M., Rodriguez H. (2002): Free radical-induced damage to DNA: mechanism and measurement. Free Radical Bio. Med., 32 (11): 1102-1115.

Fang Y-Z., Yang Sh., Wu G. (2002): Free Radicals, Antioxidants, and Nutrition. Nutrition, 18: 872-879.

Food and Nutrition Board, Institute of Medicine Washington (2000): Dry dietary reference intakes for vitamin $\mathrm{C}$, vitamin $\mathrm{E}$, selenium, and carotenoids. A Report of the Panel on Dietary Antioxidants and Related Compounds, Subcommittees on Upper Reference Levels of Nutrients and Interpretation and Uses of Dietary Reference Intakes, and the Standing Committee on the Scientific Evaluation of Dietary Reference Intakes, pp 35-57. National Academy press, Washington D.C.

Gacche R.N., Kabaliye V.N., Dhole N.A., Jadhav A.D. (2010): Antioxidant potential of selected vegetables commonly used in diet in Asian subcontinent. Indian. J. Nat. Prod. Resour, 1 (3): 306-313.

Gennari L., Felletti M., Blasa M., Angelino D., Celeghini C., Corallini A., Ninfalia P. (2011): Total extract of Beta vulgaris var. cicla seeds versus its purified phenolic components: Antioxidant activities and antiproliferative effects against colon cancer cells. Phytochem. Anal., 22: 272-279.

Gil M.I., Ferreres F., Tomás- Barberán F.A. (1998): Effect of modified atmosphere packaging on the flavonoids and vitamin $\mathrm{C}$ content of minimally processed Swiss chard (Beta vulgaris subspecies cycla). J. Agric. Food Chem., 46: 2007-2012. 
Gupta V.K. \& Sharma S.K. (2006): Plants as natural antioxidants. Nat.Prod. Radiance, 5 (4): $326-334$.

Halvorsen B.L., Holte K., Myhrstad M. C.W., Barikmo I., Hvattum E., Remberg S.V., Wold A. B., Haffner K., Baugerød H.,Andersen L.F., Moskaug J.Ø., Jacobs Jr D.R., Blomhoff R. (2002): A systematic screening of total antioxidants in dietary plants. J. Nutr., 132: 461-471.

Hamid A. A., Aiyelaagbe O. O., Usman L. A., Ameen O. M., Lawal A. (2010): Antioxidants: Its medicinal and pharmacological applications, AJPAC, 4(8): 142-151.

Heim K.E., Tagliaferro A.R., Bobilya D.J. (2002): Flavonoid antioxidants: chemistry, metabolism, and structure-activity relationships, J. Nutr. Biochem. 13: 572-584.

Herrera E. \& Barbas C. (2001): Vitamin E: action, metabolism and perspectives. J. Physiol. Biochem., 57(2): 43-56.

Huang W-Y., Cai Y-Z., Zhang Y. (2009): Natural Phenolic Compounds From Medicinal Herbs and Dietary Plants: Potential Use for Cancer Prevention, Nutr. Cancer, 62(1): 1-20.

Irshad M. \& Chaudhuri P.S. (2002): Oxidant-antioxidant system: Role and significance in human body, Indian. J. Exp. Biol., 40: 1233-1239.

Ismail A., Marjan Z.M., Foong C.W. (2004): Total antioxidant activity and phenolic content in selected vegetables, Food Chem., 87: 581-586.

Kähkönen M.P., Hopia A.I., Vuorela H.J., Rauha J-P., Pihlaja K. Kujala T.S., Heinonen M. (1999): Antioxidant activity of plant extracts containing phenolic compounds. J. Agric. Food Chem. 47: 3954-3962.

Kaur C. \& Kapoor H.C. (2001): Antioxidants in fruits and vegetables - the millennium's health. Int. J. Food Sci. Technol., 36: 703-725.

Kumar S. \& Pandey A.K. (2013): Chemistry and Biological Activities of Flavonoids: An Overview, Scientific World J. 1-16.

Lampe J.W. (1999): Health effects of vegetables and fruit: assessing mechanisms of action in human experimental studies1-3. Am. J. Clin. Nutr., 70 (3): 475s-490s.

Lange W., Brandeburg W.A., De Bock T.S.M. (1999): Taxonomy and cultonomy of beet (Beta vulgaris L.), Bot. J. Linn. Soc.130: 81-96.

Leopoldini M., Marino T., Russo N., Toscano M. (2004): Antioxidant Properties of Phenolic Compounds: H-Atom versus Electron Transfer Mechanism, J. Phys. Chem. A, 108: 4916-4922.

Masayuki Y. \& Shoichi H. (1997): Extraction of blood glucose sugar lowering saponins from Beta vulgaris, Jpn. Kokai Tokkyo Koho JP 0925290 (Appl. 95:177. 220, 1995), 9 pp (Japan). Chemical Abstract 126 203699c.

Montuschi, P., Barnes, P. J., Roberts, L J. (2004): II. Isoprostanes: markers and mediators of oxidative stress. FASEB J, 18(15): 1791-1800.

Mueller L. \& Boehm V. (2011): Antioxidant activity of $\beta$-carotene compounds in different in vitro assays, Molecules, 16: 1055-1069.

Ninfali P. \& Angelino D. (2013): Nutritional and functional potential of Beta vulgaris cicla and rubra. Fitoterapia 89: 188-199.

Ninfali P. \& Bacchiocca M. (2003): Polyphenols and antioxidant capacity of vegetables under fresh and frozen conditions. J. Agric. Food Chem., 51: 2222-2226.

Ninfali P., Bacchiocca M., Antonelli A., Biagiotti E., Di Gioacchino A.M., Piccoli G., Stocchi V., Brandi G. (2007): Characterization and biological activity of the main flavonoids from Swiss Chard (Beta vulgaris subspecies cycla). Phytomedicine, 14: 216-221. 
Ninfali P., Mea G., Giorgini S., Rocchi M., Bacchiocca M. (2005): Antioxidant capacity of vegetables, spices and dressings relevant to nutrition. Br. J. Nutr., 93: 257-266.

Olson J.A. \& Krinsky N.I. (1995): Introduction: the colorful fascinating world of the carotenoids: important physiologic modulators. FASEB J., 9: 1547-1550.

Pacher P., Beckman J.S., Liaudet L. (2007): Nitric oxide and peroxynitrite in health and disease. Physiol. Rev., 87: 315-424.

Packer L., Weber S.U., Rimbach G. (2001): Molecular aspects of $\alpha$-tocotrienol antioxidant action and cell signalling, J. Nutr. 131: 369S-373S.

Pham-Huy L.A., He H., Pham-Huy C. (2008): Free Radicals, Antioxidants in Disease and Health. Int. J. Biomed. Sci., 4 (2): 89-96.

Pokluda R. \& Kuben J. (2002): Comparison of selected Swiss chard (Beta vulgaris ssp. cicla L.) varieties. Hort. Sci. (Prague), 29(3): 114-118.

Pyo Y-H., Lee T-C., Logendra L., Rosen R.T. (2004): Antioxidant activity and phenolic compounds of Swiss chard (Beta vulgaris subspecies cycla) extracts. Food Chem., 85: 19-26.

Ramarathnam N., Osawa T., Ochi T., Kawakishi S. (1995): The contribution of plant food antioxidants to human health. Trends Food Sci. Tech., 6: 75-82.

Rice-Evans, C.-A.; Miller, N.J.; Bolwell, P.G.; Bramley, P.M.; Pridham, J.B. (1995): The relative antioxidant activities of plant-derived polyphenolic flavonoids. Free Radical Res., 22: 375-383.

Rimm E.B., Ascherio A., Grovannucci E., Spielgelman D., Stampfer M.J., Willett WC. (1996): Vegetable, fruit, and cereal fiber intake and risk of coronary heart disease among men. JAMA, 275: 447-451.

Sacan O. \& Yanardağ R. (2010): Antioxidant and antiacetylcholinesterase activities of chard (Beta vulgaris L. var. cicla). Food Chem. Toxicol., 48: 1275-1280.

Salvi A., Carrupt P-A., Tillement J-P., Testa B. (2001): Structural damage to proteins caused by free radicals: asessment, protection by antioxidants, and influence of protein binding. Biochem. Pharmacol. 61: 1237-1242.

Santos J., Oliveira M.B.P.P., Ibáñez E., Herrero M. (2014): Phenolic profile evolution of different ready-to-eat baby-leaf vegetables during storage. J. Chromatogr. A, 1327: 118-131.

Sener G, Saçan O, Yanardă̆ R, Ayanoğlu-Dülger G. (2002): Effects of chard (Beta vulgaris L. var. cicla) extract on oxidative injury in the aorta and heart of streptozotocin-diabetic rats. J. Med. Food., 5(1): 37-42.

Sies H. \& Stahl W. (1995): Vitamins E and C, beta-carotene, and other carotenoids as antioxidants. Am. J. Clin. Nutr. 62: 1315S-1321S.

Sies H. \& Stahl W. (1995): Vitamins E and C, $\beta$-carotene, and other carotenoids as antioxidants, Am J Clin. Nutr., 62: 1315S-1325S.

Sindhi V., Gupta V., Sharma K., Bhatnagar S., Kumari R., Dhaka N. (2013): Potential applications of antioxidants-a review. JPR, 7: 828-835.

Sindhu E.R., Preethi K.C., Kuttan R. Antioxidant activity of carotenoid lutein in vitro and in vivo. (2010): Indian J. Exp. Biol., 48(8): 843-848.

Shalaby E.A. \& Shanab S.M.M. (2013): Antioxidant compounds, assays of determination and mode of action. Afr. J. Pharm. Pharmacol., 7(10): 528-539.

Shetty A.A., Magadum S, Managanvi K. (2013): Vegetables as sources of antioxidants. J. Food Nutr. Disor., 2 (1): 1-5.

Stadtman E.R. (1992): Protein oxidation and aging, Science, 257:1220-1225.

Stahl W. \& Sies H. (2003): Antioxidant activity of carotenoids, JMAM, 24: 345-351. 
Steimez K.A. \& Potter J.D. (1996): Vegetables, fruits and cancer prevention: a review. J. Am. Diet Assoc., 96: 1027-1039.

Tomás-Callejas A., Boluda M., Robles P.A., Artés F., Artés-Hernández F. (2011): Innovative active modified atmosphere packaging improves overall quality of fresh-cut red chard baby leaves. LWT-Food Sci. Technol., 44: 1422-1428.

Topalović A., Knežević M., Vajs V. (2013): The total phenolics and antioxidants from fruit and vegetables: an evaluation of daily intake. Agriculture and Forestry, 59(1): 143-154.

Yahia E. M. (2010): The contribution of fruit and vegetable consumption to human health, In L.A. De la Rosa, E. Alvarez-Parrilla \& G.A. Gonzalez-Aguilar, eds. Fruit and Vegetable Phytochemicals: Chemistry, Nutritional Value and Stability, pp. 3-53, Wiley-Blackwell, Ames, Iowa, USA, 357 pp.

Yanardağ R. \& Çolak H. (1998): Effect of chard (Beta vulgaris L. var. cicla) on blood glucose levels in normal and alloxan-induced diabetic rabbits. Pharm. Pharmacol. Commun., 4(6): 309-311.

Young I. \& Woodside J. (2001): Antioxidants in health and disease. J. Clin. Pathol., 54: 176-186. 